\title{
Analysis of Extractive Industry Concentration in Russia as a Factor Hindering the Sustainable Development of the Regions
}

\author{
Bato Tagarov* \\ Baikal State University, Irkutsk, Russia
}

\begin{abstract}
Modern economic growth is viewed through the prism of the paradigm of sustainable development. This work presents the reasons for the difficulties of transition to the sustainable development of an economy with a high share of extractive industry and shows that for the effective implementation of the Sustainable Development Goals it is necessary to change the economic model for reducing the role of this industry. The analysis of the extractive industry contribution to the gross regional product of Russia's regions is carried out. The work considers changes in the extractive industry share, both in the country's economy as a whole and in some of its regions. It is shown that, despite the decrease in this indicator value in most of Russia's large regions, in general, the extractive industry share in GRP has increased. The dynamics in the level of the extractive industry concentration in regions is analyzed using the Herfindahl-Hirschman Index and the Krugman Index.
\end{abstract}

\section{Introduction}

The transition to sustainable development in recent decades has become one of the main priorities of the world community. This concept was first considered at the United Nations (UN) Conference held in Stockholm in 1972. In 1992, at the UN Conference, the concept of sustainable development was defined as "... a model of moving forward, in which the life needs of the current generation are met while preserving the same opportunities for future generations" [1]. At this conference, the UN member states signed the Rio Declaration on Environment and Development, which defines the basic principles of the environmental behaviour of the states. In 2015, the document "Transforming our World: the 2030 Agenda for Sustainable Development" was adopted [2], which established the Sustainable Development Goals that allow achieving a harmonious balance between economic growth, social objectives and environmental protection. It should also be noted that in the same year, within the UN Framework Convention on Climate Change, the "Paris Agreement" was adopted (instead of the Kyoto Protocol), aimed at reducing carbon dioxide emissions.

Russia supports the idea of sustainable development and, participating in the abovementioned agreements (the Paris Agreement was signed by the Russian Federation on April $22,2016)$, takes into account the provisions of this concept in the development and

\footnotetext{
${ }^{*}$ Corresponding author: TagarovBG@bgu.ru.
} 
implementation of national projects and state programs. In particular, in 1996, the President of the Russian Federation approved the "Concept of the Country's Transition to Sustainable Development" [3], in 2002, the Federal Law "On Environmental Protection" [4] and the "Environmental Doctrine of the Russian Federation" [5] were adopted, in 2014 - the State Program of the Russian Federation "Environmental Protection" [6], etc. In July 2020, the President of the Russian Federation signed the Decree "On the National Development Goals of the Russian Federation for the Period up to 2030" [7], which specified several Sustainable Development Goals (such as "reducing the poverty level by half compared to 2017" and "reducing emissions of dangerous pollutants that have the greatest negative impact on the environment and human health by two times").

The implementation of sustainable development based on resource-saving technologies is impossible without serious structural changes in the economy. First of all, we are talking about a gradual transition from a "raw material" industrial model of development to a postindustrial society based on knowledge-based industry, in which material resources and routine work are replaced by information and knowledge.

Therefore, analyzing the role of resource-intensive industry in the country's economy, the main representative of which is the extractive industry, it is possible to conclude about the results of introducing a new development paradigm.

The purpose of this work is to analyze the changes in the extractive industry contribution to Russia's economy and the specialization level of the regions in this industry.

The subject of the research is the extractive industry contribution to the gross regional product (GRP) of the subjects of the Russian Federation.

\section{Materials and methods}

This paper analyzes the extractive industry contribution to the Russian regions' GRP from 2005 to 2019. The changes in the extractive industry GRP share of the leading regions and the largest, from an economic point of view, regions of Russia are determined. The data source was the Unified Interdepartmental Information Statistical System (UnISS) [8]. The analysis of concentration changes in regions was also carried out. The HerfindahlHirschmann Index (HHI) and the Krugman Index (KDI) were used to quantify the concentration change. The HHI was calculated using the formula:

$$
\mathrm{HHI}=\sum_{\mathrm{i}=1}^{\mathrm{n}}\left(\frac{E_{\mathrm{ij}}}{\mathrm{Ej}}\right)^{2}
$$

where Eij is the contribution of industry $\mathrm{j}$ to the GRP of region $\mathrm{i}, \mathrm{Ej}$ is the added value created in industry $\mathrm{j}$ in the economy of the country as a whole.

This index is used to determine production concentration level based on the market shares of subjects (in our case, regions). The closer the index value is to 1 , the higher the level of concentration in the industry.

KDI measures the relative concentration level. It shows how high the level of the regions' specialization in this activity is:

$$
\operatorname{KDIj}=\sum_{i=1}^{n}\left|\frac{E i j}{E j}-\frac{E i}{E}\right|
$$

where $\mathrm{Ei}$ is the GRP of region $\mathrm{i}, \mathrm{E}$ is the total GRP of all regions in the country.

\section{Findings}

In the current global economic system, due to international trade, a country's industrial specialization is formed based on the type of "centre-peripheral" relations. As a result, intellectually demanding activities tend to be concentrated in developed countries, while 
resource-intensive and labour-intensive activities tend to be concentrated in peripheral developing countries. The economic structure of developing countries in such a system contradicts the very idea of sustainable development since their growth is largely associated with extensive factors. Similar relations develop within countries between the "central" and "peripheral" regions; it affects the efficiency of the Sustainable Development Goals implemented at this step.

The problem of the relationship between a region's level of resource capacity, the centre-peripheral relations and the sustainability of their development has been considered by several researchers, among whom we can note F. Perroux [9], P. Krugman [10], E. Reinert [11], O. Kuznetsova [12], S. Rastvortseva [13], S. Chuprov [14], I. Grebenkin [15], V. Klimanov [16], Z. Mirzekhanova [17], M. Bagainikov [18] and many others.

In general, the following reasons can be defined for the low motivation for sustainable development among the subjects of the state, the economy of which is mainly industrial or agricultural, and the well-being of its inhabitants is associated with exploitating natural resources:

1. The specialization of the economy based on using natural resources, whether minerals, arable land or water resources, does not allow reducing the burden on the environment without losing society's income.

2. Tightening environmental standards in such spheres of activity will cause a decrease in profitability, which will affect the interests of "the elites" who receive resource rent. Moreover, the relatively low technological level of production requires a large investment to increase its environmental friendliness.

3. The low standard of living in developing countries doesn't allow creating a significant demand for environmentally friendly production and products with the population.

4. The low cost of labour is one of the important factors of the competitive ability of labour-intensive industries. Therefore, the fight against poverty within such an economic model is possible only with the help of state subsidies, which will require a tax increase.

As a result, measures aimed, for example, at protecting the environment, will face resistance from economic entities and, ultimately, will either be declarative, only formally conforming with international standards, or will cause serious economic damage [19]. Therefore, implementing the Sustainable Development Goals is fully possible in developing countries only if the resource-intensive industrial development model is changed to an information-intensive post-industrial one.

Based on the above, we can say that the dynamics of the resource-intensive industry share in the economy is one of the main indicators of the implementation of the sustainable development concept.

A country's transition to sustainable development should be implemented not only at the national but also at the regional level. It's most significant for a country like Russia. The fact is that such a large country's economy geographically is very heterogeneous and the structure of production in the regions can differ significantly.

We will consider the role of the extractive industry in the structure of the Russian economy, the specialization of regions in this industry and the dynamics in its share in the gross regional product (GRP). This analysis will allow us to understand how much Russia managed to overcome its dependence on natural resource exploitation and put its economy on the "rails" of sustainable development.

The extractive industry share in the structure of the Russian economy increased from $12.76 \%$ in 2005 to $13.52 \%$ in 2019 . These statistics show that over the past 15 years the dependence of the Russian economy on the raw material sector hasn't decreased but even increased in some way. For comparison, at the end of 2019 in the United States, the extractive industry share in GNP was $1.4 \%$ [20], in the European Union - 0.4\% [21]. 
Table 1 shows Russia's 15 regions that had the largest share of the extractive industry in GRP at the end of 2005.

Table 1. The change in the extractive industry share in the GRP structure of Russia's regions.

\begin{tabular}{|c|c|c|c|}
\hline \multirow[b]{2}{*}{ Region } & \multicolumn{2}{|c|}{$\begin{array}{l}\text { Extractive industry } \\
\text { share in GRP of the } \\
\text { region }\end{array}$} & \multirow{2}{*}{$\begin{array}{r}\text { rate of } \\
\text { growth, } \\
2005 / 2019\end{array}$} \\
\hline & 2005 & 2019 & \\
\hline Perm Krai & 0.157 & 0.226 & 1.440 \\
\hline Kursk region & 0.180 & 0.130 & 0.723 \\
\hline Republic of Karelia & 0.193 & 0.187 & 0.968 \\
\hline Arkhangelsk Region & 0.207 & 0.322 & 1.558 \\
\hline Belgorod region & 0.219 & 0.192 & 0.879 \\
\hline Sakhalin Region & 0.221 & 0.642 & 2.907 \\
\hline Udmurt Republic & 0.266 & 0.274 & 1.030 \\
\hline Kemerovo Region - Kuzbass & 0.270 & 0.262 & 0.970 \\
\hline Magadan Region & 0.271 & 0.451 & 1.662 \\
\hline Republic of Tatarstan (Tatarstan) & 0.309 & 0.288 & 0.931 \\
\hline Komi Republic & 0.343 & 0.437 & 1.274 \\
\hline Tomsk Region & 0.354 & 0.275 & 0.777 \\
\hline Orenburg Region & 0.369 & 0.409 & 1.109 \\
\hline Republic of Sakha (Yakutia) & 0.395 & 0.506 & 1.282 \\
\hline Tyumen Region & 0.598 & 0.643 & 1.075 \\
\hline
\end{tabular}

Source: the author's calculations based on UnISS data [8].

The table shows that most regions' specialization (9 out of 15) in extracting minerals increased over the period under review. This is especially true for the Sakhalin Region, the Magadan Region, the Arkhangelsk Region and the Perm Region. Nevertheless, some regions, for example, the Tomsk Region and the Republic of Tatarstan, were able to reduce their dependence on the raw material sector.

A certain increase in the extractive industry specialization of the most "raw material" regions is confirmed by the data from Table 2, which contains information about Russia's 10 largest regions in terms of value added created in these industries.

Table 2. Russia's largest regions in terms of GRP created in the extractive industry.

\begin{tabular}{|c|c|c|}
\hline \multirow{2}{*}{ Regions } & \multicolumn{2}{|c|}{$\begin{array}{r}\text { GRP created in the extractive industry } \\
\text { (thousand rubles) }\end{array}$} \\
\cline { 2 - 3 } & $\mathbf{2 0 0 5}$ & $\mathbf{2 0 1 9}$ \\
\hline Komi Republic & $58,692,126$ & $314,606,998.8$ \\
\hline Samara Region & $43,464,873$ & $317,101,336$ \\
\hline Perm Krai & $51,348,165$ & $337,845,344.3$ \\
\hline Irkutsk Region & $9,700,857$ & $451,636,983.5$ \\
\hline Orenburg Region & $78,637,730$ & $453,150,274$ \\
\hline Krasnoyarsk Krai & $17,342,749$ & $606,251,662.4$ \\
\hline Republic of Sakha (Yakutia) & $72,286,165$ & $617,684,245.2$ \\
\hline Sakhalin Region & $26,716,943.5$ & $753,498,367.6$ \\
\hline Republic of Tatarstan (Tatarstan) & $149,220,306$ & $804,312,847.1$ \\
\hline Tyumen Region & $1,325,895,891$ & $5,738,487,845.3$ \\
\hline $\begin{array}{c}\text { These regions' share in Russia's total GRP } \\
\text { created in the extractive industry }\end{array}$ & 0.797 & \\
\hline Source: & & 0.811 \\
\hline
\end{tabular}

Source: the author's calculations based on UnISS data [8].

Table 2 shows that the share of the regions leading in Russia's extractive industry in the national production volume in this sphere increased from $79.7 \%$ to $81.1 \%$ from 2005 to 2019. Nevertheless, this increase (by $1.7 \%$ ) is less than the increase in the extractive 
industry share in the country's economy as a whole over this period (by 5.9\%). This suggests that the concentration of the "raw material" industry in the country somewhat decreased and the growth of its share in the economy was caused by its increase in other regions (in total, the extractive industry share increased in the economy of Russia's 48 regions).

Let's consider how the concentration level of the extractive industry in Russia changed. To do this, we use the Herfindahl-Hirschmann Index (HHI) and the Krugman Index. The index values for the period from 2015 to 2019 are shown in Table 3.

Table 3. Dynamics in concentration indices in the extractive industry.

\begin{tabular}{|l|l|l|l|l|l|l|l|l|}
\hline & 2005 & 2007 & 2009 & 2011 & 2013 & 2015 & 2017 & 2019 \\
\hline HHI & 0.344 & 0.281 & 0.239 & 0.197 & 0.222 & 0.215 & 0.215 & 0.219 \\
\hline KDI & 1.241 & 1.271 & 1.273 & 1.234 & 1.266 & 1.271 & 1.281 & 1.266 \\
\hline
\end{tabular}

Source: the author's calculations based on UnISS data [8].

The dynamics of the Herfindahl-Hirschman Index shows that in the period from 2005 to 2011 there was a rather strong decrease in production concentration in this industry. After that, the index value changed slightly. The concentration level decrease is explained by the high growth rates of the extractive industry relative to the leader (the Tyumen Region) in regions rich in natural resources like the Irkutsk Region, the Krasnoyarsk Krai, the Sakhalin Region, as well as the emergence of new centres of the extractive industry, such as the Astrakhan Region (the share of this industry increased from $2.73 \%$ to $47.89 \%$ during the period under review).

In contrast to the HHI, the Krugman Index underwent very small changes, which proves that the specialization of Russian regions in the extractive industry increased but very slightly. It should be noted that KDI has the following feature: when determining a specialization level, it doesn't take into account the size of a subject relative to the economic system as a whole. Therefore, the growth of the extractive industry share in small regions can have a big impact on the final value of the indicator.

The concentration index values allow concluding that the extractive industry growth in absolute terms and its share in the country's economy is caused not only by the growth in the leading regions but also in other subjects of the Russian Federation. This suggests that the extractive industry has grown to play a more important role in more regions than at the beginning of the period under review.

Table 4 shows Russia's 10 regions with the highest GRP value at the end of 2005.

Table 4. Russia's largest regions in terms of GRP.

\begin{tabular}{|c|c|c|c|c|}
\hline \multirow{2}{*}{ Regions } & \multicolumn{2}{c|}{$\begin{array}{c}\text { Volume of GRP created in the } \\
\text { extractive industry (thousand } \\
\text { rubles) }\end{array}$} & \multicolumn{2}{c|}{$\begin{array}{c}\text { Extractive industry } \\
\text { share in the GRP } \\
\text { structure of the region }\end{array}$} \\
\cline { 2 - 5 } & $\mathbf{2 0 0 5}$ & $\mathbf{2 0 1 9}$ & $\mathbf{2 0 0 5}$ & $\mathbf{2 0 1 9}$ \\
\hline Samara Region & $43,464,873$ & $317,101,336$ & 0.108 & 0.188 \\
\hline Republic of Bashkortostan & $48,402,151$ & $62,252,081$ & 0.108 & 0.034 \\
\hline Sverdlovsk Region & $20,944,278$ & $51,860,020$ & 0.040 & 0.032 \\
\hline Krasnodar Territory & $7,133,285$ & $12,681,150$ & 0.019 & 0.005 \\
\hline Krasnoyarsk Krai & $17,342,749$ & $606,251,662$ & 0.039 & 0.225 \\
\hline $\begin{array}{c}\text { Republic of Tatarstan } \\
\text { (Tatarstan) }\end{array}$ & $149,220,306$ & $804,312,847$ & & \\
\hline $\begin{array}{c}\text { Saint Petersburg, city of federal } \\
\text { significance }\end{array}$ & 378,998 & $13,773,520$ & & 0.309 \\
\hline Moscow region & $1,280,026$ & $8,717,537$ & 0.001 & 0.288 \\
\hline Tyumen Region & $1,325,895,891$ & $5,738,487,845$ & 0.598 & 0.003 \\
\hline Moscow & 0 & 0 & 0 & 0.643 \\
\hline Russian Federation & $2,300,462,484$ & $12,820,774,261$ & - & - \\
\hline
\end{tabular}




\begin{tabular}{|c|c|c|c|c|}
\hline $\begin{array}{c}\text { These regions' share in Russia's } \\
\text { total GRP created in the } \\
\text { extractive industry }\end{array}$ & 0.702 & 0.594 & - & - \\
\hline
\end{tabular}

Source: the author's calculations based on UnISS data [8].

From the data shown in Table 4, it can be seen that in 4 out of 10 of these regions (the Samara Region, the Krasnoyarsk Krai, the Republic of Tatarstan, the Tyumen Region), the extractive industry share at the end of 2019 was quite large. In addition, the table shows that the data about 10 regions in 2005 accounted for about $70 \%$ of the total value added created in this industry in the country. And rom this we can deduce that the "raw material" regions play an important role in the economy, being the economic leaders in the country. On the other hand, by 2020, the contribution of these regions to the country's extractive industry decreased to $59 \%$, which demonstrates a certain, although not significant, reorientation of their economies to other industries.

\section{Discussion}

The statistics given in this article show that the extractive industry share in the GRP of Russian regions did not decrease during the period under review but even showed some growth. This means that Russia was not able to qualitatively rebuild its economy. The relatively high share of "raw material" industries in public production hinders sustainable development, both at the national and regional levels. For example, measures aimed at protecting the environment will face resistance from economic entities and, ultimately, will either be declarative or will cause serious economic damage.

In our previous works $[22,23]$, it was shown that scientific, educational and financial activities are increasingly concentrated in the regions of the Central and North-Western Federal Districts, primarily in Moscow and St. Petersburg. The results obtained in the framework of this research, together with data on the concentration in the above-mentioned "post-industrial" types of activities, allow us to say that the Russian economy is very heterogeneous, from the point of view of the specialization of regions in the extractive industry. The leading regions (except the Tyumen Region and the Krasnoyarsk Krai), primarily at the expense of Moscow, reduced their specialization in this industry, and some federal subjects, on the contrary, increased it. It is these regions with a high share of the extractive industry that will experience the greatest difficulties in achieving the Sustainable Development Goals.

\section{Conclusion}

A state the economy of which has a high share of the extractive industry will have the following problems when implementing the concept of sustainable development: the inability to reduce the burden on the environment without losing the society's income, the need for large investments to improve the environmental friendliness of production, the need for relatively cheap labour.

The specialization of the most "raw material" regions of Russia in the extractive industry has increased in some way. Moreover, the share of this industry increased in 48 regions of Russia during the period under review. In general, this share in the total GRP of the Russian regions increased from $12.76 \%$ in 2005 to $13.52 \%$ in 2019.

The Herfindahl-Hirschman Index in this period decreased from 0.344 to 0.219 , while the Krugman Index practically did not change (1.241 in 2015 and 1.266 in 2019). The concentration index values allow proving the conclusion that the extractive industry growth in absolute terms and its share in the country's economy is caused not only by the growth in the leading regions but also in other subjects of the Russian Federation. 


\section{References}

1. UN:

Agenda

21.

https://www.un.org/ru/documents/decl_conv/conventions/agenda21.shtml

2. UN: 2030 Agenda for Sustainable Development. https://www.un.org/sustainabledevelopment/ru/about/development-agenda/

3. Decree of the President of the Russian Federation of April 1, 1996 N 440 "On the Concept of the Transition of the Russian Federation to Sustainable Development"

4. Federal Law of 10.01.2002 N 7-FZ "On Environmental Protection".

5. Order of the Government of the Russian Federation of August 31, 2002 N 1225-r "On the Environmental Doctrine of the Russian Federation".

6. Decree of the Government of the Russian Federation of 15.04.2014 N 326 "On approval of the state program of the Russian Federation" Environmental protection ".

7. Decree of the President of the Russian Federation of July 21, $2020 \mathrm{~N} 474$ "On the national development goals of the Russian Federation for the period up to 2030".

8. Unified Interdepartmental Information and Statistical System (EMISS). https://www.fedstat.ru

9. F. Perroux, Spatial Economics 2, 92 (2007)

10. P. Krugman, J. of Political Economy 99, 483 (2007)

11. E. Reinert, How rich countries became rich and why poor countries remain poor, 384 p. (Moscow: Publishing House State University - Higher School of Economics, 2011)

12. O.V. Kuznetsova, Territorial development problems 5(97), 26 (2018) doi: 10.15838/ptd.2018.5.97.2.

13. S. N. Rastvortseva, Economic and social changes: facts, trends, forecast 11(1), 84 (2018)

14. S. V. Chuprov, Bulletin of the Baikal State University 4, 507 (2020). doi: 10.17150/25002759.2020.30 (4) .507-515.

15. I.V. Grebyonkin, Economy of Region 16(1), 69 (2020). doi: https://doi.org/10.17059/2020-1-6.

16. Z.G. Mirzekhanova, Economy of Region 16(2), 449 (2020). doi: http://doi.org/10.17059/2020-2-9

17. V. V. Klimanov S. M. Kazakova, A. A. Mikhailova, Economic Issues 5, 1 (2019)

18. M.L. Bagainikov, Bulletin of the Baikal State University 27(3), 359 (2017). doi: 10.17150/25002759.2017.27 (3) .359-365

19. E. M. Yakimova, V. V. Chuksina, G. N. Komkova, S. E. Nesmeyanova, Russian Journal of Criminology. 12(2), 288 (2018) doi: 10.17150/2500-4255.2018.12 (2) .288298

20. Bureau of economic analysis. https://www.bea.gov/sites/default/files/202103/gdp4q20_3rd.pdf

21. Eurostat.

https://ec.europa.eu/eurostat/databrowser/view/NAMA_10_A64_custom_1077012/de fault/table?lang=en

22. B. Zh. Tagarov, Creative Economy 14(6), 1021 (2020). doi: 10.18334/ce.14.6.110185

23. B. Zh. Tagarov, Economics, Entrepreneurship and Law 10(7), 1921 (2020). doi: 10.18334/epp.10.7.110449 